\title{
Further Studies on the Repression of Methionine Synthesis in Escherichia coli
}

\author{
BY R. J. ROWBURY AND D. D. WOODS \\ Microbiology Unit, Department of Biochemistry, University of Oxford
}

(Received 25 July 1960)

\section{SUMMARY}

The observation that growth in the presence of methionine results in organisms with a greatly decreased ability to form methionine from homocysteine has been extended to other strains of Escherichia coli, in particular strain PA 15, an organism for which there is a considerable background of knowledge concerning the enzymic mechanism of this stage of methionine synthesis. When organisms grown in the absence of methionine ('active' organisms) are transferred to a medium containing methionine the activity is not lost, but simply diluted by new organisms having much less activity. Both organisms and ultrasonic extracts derived from them show the same comparative loss of activity when the organisms are incubated with methionine.

Organisms grown in the presence of methionine ('inactive' organisms) regain activity when incubated in a growth medium without methionine. The major part of such regeneration of activity occurs before growth is significant. Enzyme formation occurs linearly and without lag and is stopped by the addition of methionine at any stage. A number of analogues of methionine also repress enzyme formation, but none is as active as methionine.

Regeneration of enzyme is inhibited by chloramphenicol and is greatly diminished when the supply of individual amino acids is restricted either by the use of an inhibitory analogue ( $p$-fluorophenylalanine) or by the use of amino acid-requiring auxotrophs. Formation of enzyme therefore requires de novo synthesis of protein. Similar techniques gave no evidence that concurrent synthesis of ribonucleic acid was also required.

Compounds which act as substrates or cofactor for methionine synthesis (serine, homocysteine, cobalamin) also repressed enzyme formation to some extent and, after a lag, full repression was obtained with a mixture of all three. These effects are probably due to methionine itself whose synthesis by the enzyme initially present is stimulated by the test substances.

\section{INTRODUCTION}

In earlier work in this laboratory it was shown that growth of a number of strains of Escherichia coli in a medium containing methionine resulted in an almost total loss by the organisms of their ability to form methionine from homocysteine and serine. Furthermore, strong evidence was obtained that the change was a purely phenotypic one (Wijesundera \& Woods, 1953, 1960). The phenomenon thus appeared to be a typical case of enzyme repression (Vogel, 1957) by the ultimate 
product of the activity of the enzyme in question. All the earlier work, and also that of Cohn, Cohen \& Monod (1953), had been carried out with intact organisms and it remained theoretically possible that the failure to metabolize homocysteine after growth on methionine was due to a loss of the ability of homocysteine to permeate the organism. Part of the object of the present work was to determine by experiments with cell-free enzyme preparations whether enzymic activity for the conversion of homocysteine to methionine was also lacking or reduced after culture on methionine.

It was also shown (Wijesundera \& Woods, 1960) that a single subculture in the absence of methionine completely restored the ability of the organisms to synthesize this amino acid. A second object of the present work was to determine under more controlled conditions the factors necessary for the production of the enzyme, and particularly whether de novo synthesis of protein occurred. A similar study of the synthesis of the enzyme ornithine transcarbamylase was made by Maas \& Gorini (1957); the formation of this enzyme, which is concerned in the synthesis of arginine, is repressed by growth of the organism (Escherichia coli) in the presence of arginine.

Following the terminology of Wijesundera \& Woods (1960) 'inactive' organisms will be used in reference to organisms harvested after growth in the presence of methionine and having severely restricted ability to convert homocysteine to methionine; 'active' organisms are those which have not been exposed to methionine.

The strain (PA15) of Escherichia coli used for most of the work was chosen because there was a considerable background of knowledge, both with intact organisms and cell-free enzyme preparations, concerning the mechanism of the reaction between homocysteine and serine which yields methionine (Gibson \& Woods, 1960; Szulmajster \& Woods, 1960; Kisliuk \& Woods, 1960; Guest, Helleiner, Cross \& Woods, 1960).

\section{METHODS}

Organisms. Escherichia coli PA15 is an auxotroph requiring serine or glycine for growth; it was obtained originally from Dr Barbara Wright. Other strains used for certain experiments required for growth arginine and uracil (C21), thymine (15 $\mathrm{T}^{-}$) and homocysteine or methionine (26/18). All strains were maintained on tryptic digest of meat agar slopes, subcultured monthly and stored at $4^{\circ}$ after incubation for $18 \mathrm{hr}$. at $37^{\circ}$.

Preparation of suspensions of organisms. The basal medium (GL) used throughout was the glucose + lactate medium of Guest et al. (1960); it was normally supplemented with glycine (10m M) for strain PA15, though DL-serine (10 mM) was used in some experiments. Other supplements were: uracil $(\mathrm{mM})+\mathrm{L}$-arginine $(10 \mathrm{mM})$ for strain C21; thymine (mM) for strain $15 \mathrm{~T}^{-}$; DL-homocysteine (mM) for strain 26/18).

The inoculum for the main cultures was developed as follows. Medium GL $(6 \mathrm{ml}$.) containing the appropriate growth factor was dispensed in $150 \times 150 \times 16 \mathrm{~mm}$. $\perp$-shaped tubes (Monod, Cohen-Bazire \& Cohen, 1951) and autoclaved at $115^{\circ}$ for $7 \mathrm{~min}$. After seeding from an $18 \mathrm{hr}$. culture on tryptic digest of meat agar the tubes were rocked for $8 \mathrm{hr}$. at $37^{\circ}$ at 36 oscillations $/ \mathrm{min}$. of excursion $10 \mathrm{~cm}$. 
The main cultures were grown in 1 l. conical flasks containing 200-500 ml. of medium GL supplemented with the appropriate growth factors and autoclaved at $115^{\circ}$ for $7 \mathrm{~min}$. After inoculation the flasks were shaken (circular motion, 220 rotations/min. of radius $2 \mathrm{~cm}$.) in air at $37^{\circ}$ for $16-18 \mathrm{hr}$. The size of the inoculum was so adjusted $(0.05-0.5 \mathrm{ml}$. of the liquid culture described above) that the culture density with the various strains reached the equivalent of $0.2-0.7 \mathrm{mg}$. dry wt. organism $/ \mathrm{ml}$. in the time stated. These precautions were taken in order to obtain young cultures of approximately similar physiological age with all strains. The organisms were harvested by centrifuging $(15 \mathrm{~min}$. at $2000 \mathrm{~g}$ ) and washed once with the culture volume of water. For direct tests of ability to synthesize methionine they were resuspended at a concentration equiv. $0.3-0.4 \mathrm{mg}$. dry $\mathrm{wt}$. $/ \mathrm{ml}$. in $0.066 \mathrm{M}$ potassium phosphate buffer $\mathrm{pH} 7 \cdot 4$.

Preparation of extracts of organisms. Enzyme-containing extracts were prepared by resuspending washed organisms in water (20-30 $\mathrm{mg}$. dry wt./ml.) and subjecting to ultrasonic vibration and further treatment as described by Guest et al. (1960). The protein content of the final preparation was determined spectrophotometrically according to Layne (1957). Extract of heated Escherichia coli (strain PA15) was also prepared according to Guest et al. (1960).

Study of enzyme formation. Organisms were harvested from medium GL (supplemented with appropriate growth factors) but containing also $10 \mathrm{mM}$-DL-methionine. After washing as above they were resuspended at about $0.3 \mathrm{mg}$. dry wt. $/ \mathrm{ml}$. in fresh medium, but with methionine omitted. The suspension $(100 \mathrm{ml}$. in 1 l. conical flasks) was shaken at $37^{\circ}$ as described for the growth of cultures. Samples were removed at intervals (usually hourly) to determine the extent of growth and the ability to synthesize methionine. In the latter case the organisms were centrifuged out, washed with the sample volume of water, resuspended in $0.066 \mathrm{M}$-potassium phosphate buffer ( $\mathrm{pH} \mathrm{7 \cdot 4)}$ ) and assayed as described below. In some experiments cell-free enzyme activity was also measured: in this case it was necessary to have larger samples and to start with a larger $(250 \mathrm{ml}$.) volume of suspension. Ultrasonic treatment was as described above.

Measurement of the synthesis of methionine. In the case of intact organisms the procedure was similar to that of Gibson \& Woods (1960). The washed organisms were suspended at a concentration equiv. $c .0 .17 \mathrm{mg}$. dry wt. $/ \mathrm{ml}$. in solution MSA which contained: DL-homocysteine (6 mM) DL-serine (10 $\mathrm{mM}$ ) (or, in some experiments, glycine $(10 \mathrm{~mm}))$, glucose $(20 \mathrm{~mm})$, cobalamin $(18.4 \mu \mathrm{mm})$ and potassium phosphate buffer ( $\mathrm{pH} 7 \cdot 4 ; 33 \mathrm{~mm}$ ). Reactions were carried out in a final volume of $2 \mathrm{ml}$. After incubation for $3 \mathrm{hr}$. in air at $37^{\circ}$ the suspensions were heated at $100^{\circ}$ for $10 \mathrm{~min}$., centrifuged and the supernatant fluids assayed for methionine. A control in which the complete reaction mixture had been heated initially at $100^{\circ}$ for 5 min. was included in each experiment.

The test for methionine synthesis by ultrasonic extracts of organisms was based on the procedure of Guest et al. (1960). The enzyme at a final concentration of $2 \cdot 5$ $5 \mathrm{mg}$. protein $/ \mathrm{ml}$. was added to solution MSB which contained in potassium phosphate buffer $(0 \cdot 125 \mathrm{M} ; \mathrm{pH} \mathrm{7 \cdot 8)}$ : L-serine $(5 \mathrm{~mm})$, DL-homocysteine (5 mM), glucose (10 $\mathrm{mm}), \mathrm{MgCl}_{2}(5 \mathrm{~mm}$ ), adenosine triphosphate (5 mM), diphosphopyridine nucleotide (0.5 mM), pyridoxal phosphate $(0.25 \mathrm{~mm})$ and either extract of heated Escherichia coli $(0.1 \mathrm{ml} . / \mathrm{ml}$.) or tetrahydropteroylglutamic acid $(0.5 \mathrm{~mm})+$ cobalamin 
$(0 \cdot 37 \mu \mathrm{M})$. In some experiments serine was replaced as donor of the one carbon atom unit by glycine ( $5 \mathrm{~mm}$ ) or by the formaldehyde derivative of tetrahydropteroylglutamic acid (1.65 mM); in the latter case formaldehyde was mixed with tetrahydropteroylglutamic acid (Kisliuk \& Woods, 1960) before adding to the reaction mixture and the concentration of homocysteine was decreased to a half. The tests were carried out in a final volume of $2 \mathrm{ml}$. and incubation was at $37^{\circ}$ for $3 \mathrm{hr}$. under an atmosphere of $\mathrm{H}_{2}$. After heating $\left(100^{\circ}, 3 \mathrm{~min}\right.$.) the reaction mixture was centrifuged to remove precipitated protein and the supernatant fluid used for the assay of methionine. In each experiment there was a control in which the complete reaction mixture was heated initially to $100^{\circ}$ for $5 \mathrm{~min}$.

Methionine was determined microbiologically with Leuconostoc mesenteroides (Streptococcus equinus) P60 as described by Gibson \& Woods (1960). It was found incidentally that this organism responds as well to DL-methionine sulphoxide as to DL-methionine.

Measurement of mass of organisms. Extent of growth and the dry weight of organisms was assessed as described by Wijesundera \& Woods (1960) using an EEL photoelectric colorimeter (Evans Electroselenium, Halstead, Essex). For strain PA15 a reading of 15 corresponded to a dry weight of $0.5 \mathrm{mg} . / \mathrm{ml}$.

Expression of results. Since the interest was in enzyme activity per unit of organism rather than in total enzyme present in a culture or suspension, results have been expressed as $\mu$ mole L-methionine formed/mg. dry wt. organism. In the case of cell-free extracts the basis used is $\mathrm{mg}$. protein of the extract.

Chemicals. Most of the special chemicals used were as described by Guest $e t$ al. (1960). DL-Methionine sulphoxide was a laboratory specimen (m.p. 237 ${ }^{\circ}$ uncorrected) whose origin could not be traced. The sources of other analogues of methionine were: DL- $\alpha$-methylmethionine (Sigma Chemical Co., St Louis, Mo., U.S.A.); L-S-methyl-cysteine (California Corporation for Biochemical Research, Los Angeles, U.S.A.); DL-methionine sulphone (Nutritional Biochemicals Inc., Cleveland, Ohio, U.S.A.); DL-ethionine (Roche Products Ltd., Welwyn Garden City, Herts).

The analogues and other amino acids were tested for possible contamination with methionine by assay with Leuconostoc mesenteroides $\mathbf{P} 60$. They were also tested by chromatography on paper; descending chromatograms were developed on Whatman no. 1 paper with a saturated solution of water in collidine and with ninhydrin (2\% in $n$-butanol saturated with water) as detecting agent. Methionine and possible impurities were used as markers.

\section{RESULTS}

Since the strains of Escherichia coli used in the present work differed from those studied by Wijesundera \& Woods (1960) it was first necessary to establish that growth in the presence of methionine also decreased the ability of the present strains to synthesize methionine from homocysteine. This proved to be the case (Table 1), 90-100\% repression being obtained with strain PA15 and two other strains; the repression was, however, only about $60 \%$ with the strain requiring either homocysteine or methionine for growth.

With the one strain tested (PA15) the ability of organisms grown without methionine to synthesize this amino acid varied somewhat with the age of the culture 
from which the organisms were harvested. It was maximal at a culture density of $0.5 \mathrm{mg}$. dry wt. $/ \mathrm{ml}$., but was only $30 \%$ at $1.5 \mathrm{mg}$. dry wt. $/ \mathrm{ml}$. Young cultures were therefore used for the remaining work.

Table 1. Effect of growth with methionine on the synthesis of methionine by various strains of Escherichia coli

Organisms grown on medium GL (plus stated growth factor) with and without DLmethionine $(10 \mathrm{~mm})$. Organisms were harvested at a similar stage of growth and tested for methionine synthesis in solution MSA; incubated $3 \mathrm{hr}$.

\begin{tabular}{|c|c|c|c|c|}
\hline \multirow[b]{2}{*}{ Strain } & \multirow[b]{2}{*}{$\begin{array}{c}\text { Growth factor(s) } \\
\text { added }\end{array}$} & \multicolumn{2}{|c|}{$\begin{array}{l}\text { L-Methionine formed } \\
\text { ( } \mu \text { mole/mg. dry wt.) }\end{array}$} & \multirow[b]{2}{*}{$\begin{array}{c}\% \text { decrease } \\
\text { when } \\
\text { methionine } \\
\text { present } \\
\text { during growth }\end{array}$} \\
\hline & & $\begin{array}{c}\text { Methionine } \\
\text { absent } \\
\text { during } \\
\text { growth }\end{array}$ & $\begin{array}{c}\text { Methionine } \\
\text { present } \\
\text { during } \\
\text { growth }\end{array}$ & \\
\hline PA15 & Glycine & $2 \cdot 40$ & $0 \cdot 10$ & 96 \\
\hline C21 & Uracil + arginine & 0.90 & 0.07 & 92 \\
\hline $15 \mathrm{~T}$ & Thymine & 1.05 & $0 \cdot 11$ & 90 \\
\hline $26 / 18$ & Homocysteine & 0.84 & $0 \cdot 31$ & 63 \\
\hline
\end{tabular}

Table 2. Effect of growth on methionine on the activity of ultrasonic extracts of Escherichia coli $P A 15$

Organisms were grown on medium GL + glycine with the stated concentration of methionine. Ultrasonic extracts prepared from the harvested organisms and assayed for methionine synthesis in solution MSB. Cobalamin $(0.37 \mu \mathrm{M})$ was present in all tests in which tetrahydropteroylglutamate or its formaldehyde derivative was used. Incubated $3 \mathrm{hr}$. $\mathrm{EHC}=$ extract of heated $\mathrm{E}$. coli $; \mathrm{PtH}_{4} \mathrm{G}=$ tetrahydropterolyglutamic acid and $\mathrm{PtH}_{4} \mathrm{G}-\mathrm{CH}_{2} \mathrm{O}=$ its formaldehyde derivative.

\begin{tabular}{|c|c|c|c|c|c|c|}
\hline $\begin{array}{l}\mathbf{C}_{1} \text { donor } \\
\text { Folic acid cofactor }\end{array}$ & $\cdots$ & $\begin{array}{c}\text { Serine } \\
\text { EHC }\end{array}$ & $\left.\begin{array}{l}\text { Serine } \\
\mathrm{PtH}_{4} \mathrm{G}\end{array}\right\}$ & $\begin{array}{l}\mathrm{PtH}_{4} \mathrm{G} \\
-\mathrm{CH}_{2} \mathrm{O}\end{array}$ & $\left\{\begin{array}{l}\text { Glycine } \\
\text { EHC }\end{array}\right.$ & $\begin{array}{c}\text { Glycine } \\
\mathrm{PtH}_{4} \mathrm{G}\end{array}$ \\
\hline DL-Methionine (M) & & \multicolumn{5}{|c|}{ L-Methionine formed ( $\mu \mathrm{m}$ mole/mg. protein) } \\
\hline 0 & & 170 & 180 & 61 & 40 & 40 \\
\hline $10^{-6}$ & & 158 & 173 & 57 & 39 & - \\
\hline $10^{-5}$ & & 141 & 151 & 51 & 39 & - \\
\hline $10^{-4}$ & & 122 & 117 & 35 & 31 & - \\
\hline $10^{-3}$ & & 34 & 34 & 20 & 18 & - \\
\hline $10^{-2}$ & & 22 & 25 & 17 & 15 & 10 \\
\hline
\end{tabular}

Comparable figures ( $\mu \mathrm{m}$ mole L-methionine/mg. dry wt.) for whole organisms tested with serine as $C_{1}$ donor were (M concentration of DL-methionine in growth medium in parenthesis) $1700(0)$, $1500\left(10^{-6}\right), 1300\left(10^{-5}\right), 780\left(10^{-4}\right), 240\left(10^{-3}\right)$ and $140\left(10^{-2}\right)$.

\section{Enzymic extracts of organisms grown in the presence of methionine}

Guest et al. (1960) established three conditions for the synthesis of methionine from homocysteine by ultrasonic extracts of Escherichia coli PA15 according to the nature of the donor of the $\mathrm{C}_{1}$ unit and of the source of folic acid acting as the cofactor for the $\mathrm{C}_{1}$ transfer reaction. These were: (1) serine as donor and extract of heated $E$. coli as cofactor; (2) serine as donor and tetrahydropteroylglutamate (in the presence of cobalamin) as cofactor; (3) the formaldehyde derivative of 
tetrahydropteroylglutamate (again in the presence of cobalamin) both as donor and cofactor. Extracts of organisms grown in the presence of a range of concentrations of methionine were tested under all three conditions; in addition glycine was used as $\mathrm{C}_{1}$ donor in place of serine under conditions (1) and (2). In all cases growth in the presence of methionine at $10 \mu \mathrm{M}$ and above led to significant decrease in enzyme activity; at $10 \mathrm{~mm}$ the decrease reached 80-90\% (Table 2). The sharpest increase in repression occurred between $0.1 \mathrm{~mm}$ and $\mathrm{mm}$ methionine. The maximum degree of repression was not, however, quite so great as that observed with intact organisms (about $95 \%$ ). Mixtures of ultrasonic extracts prepared from 'active' and 'inactive' organisms had an activity equal to the sum of the separate activities; the 'inactive' extracts therefore did not contain an inhibitor.

Synthesis of methionine with glycine as $\mathrm{C}_{1}$ donor is less active than with serine, but marked repression was again obtained (Table 2). Growth of strain $26 / 18$ on homocysteine instead of methionine increased the activity of ultrasonic extracts by two- to threefold.

\section{Loss of ability to synthesize methionine}

'Active' organisms were resuspended in fresh medium GL + methionine and incubated with shaking. Samples were removed, the organisms re-harvested and again tested for their ability to synthesize methionine. The specific activity of the organisms decreased as would be expected if new enzyme were formed only in the restricted amount anticipated for organisms growing with methionine. The total activity present in the culture rose only slowly and the activity per unit organism decreased theoretically with the increasing amount of new growth (Fig. 1). The theoretical curve in Fig. 1 was computed on the assumption (from previous experiments) that the specific activity of organisms grown in the presence of methionine is $0.12 \mu$ mole L-methionine/mg. dry wt. $/ 3 \mathrm{hr}$. Then if the original activity of the organisms grown without methionine is $a \mu$ mole L-methionine $/ \mathrm{mg}$. dry wt. $/ 3 \mathrm{hr}$., then the specific activity after $n$ generations is

$$
a / 2^{n}+0 \cdot 12\left(2^{n}-1\right) / 2^{n} \text {. }
$$

A control in which the organisms were resuspended in medium GL without methionine showed no significant changes in specific activity (Fig. 1).

When the harvested organisms were re-incubated with methionine in conditions in which no growth occurred (mM-2:4-dinitrophenol present or source of nitrogen omitted from medium GL) the specific activity of the organisms fell only very slowly $(15 \%$ in $5 \mathrm{hr}$., the time equivalent to three generations when growth occurred.

Release from repression; formation of the enzyme by growing cultures

'Inactive' organisms were harvested after growth with methionine (10 mM) and resuspended in fresh medium without methionine at a density about equal to that of the original culture at the time of harvesting. The organisms rapidly regained ability to synthesize methionine from homocysteine (Fig. 2) and even before detectable multiplication began there was usually a six- to tenfold increase in activity. A control batch of organisms resuspended in medium containing methionine maintained its low order of activity, though growth was similar to that in the 
culture without methionine (Fig. 2). Ultrasonic extracts prepared from samples taken during the period of increasing activity of the whole organisms also showed a large increase in specific activity (Fig. 3).

Effect of methionine. Addition of methionine at any stage during the recovery of enzyme activity caused the rapid cessation of new enzyme formation and the specific activity ultimately decreased as expected for the dilution of existing organisms by new organisms containing only limited enzyme activity (Fig. 4).

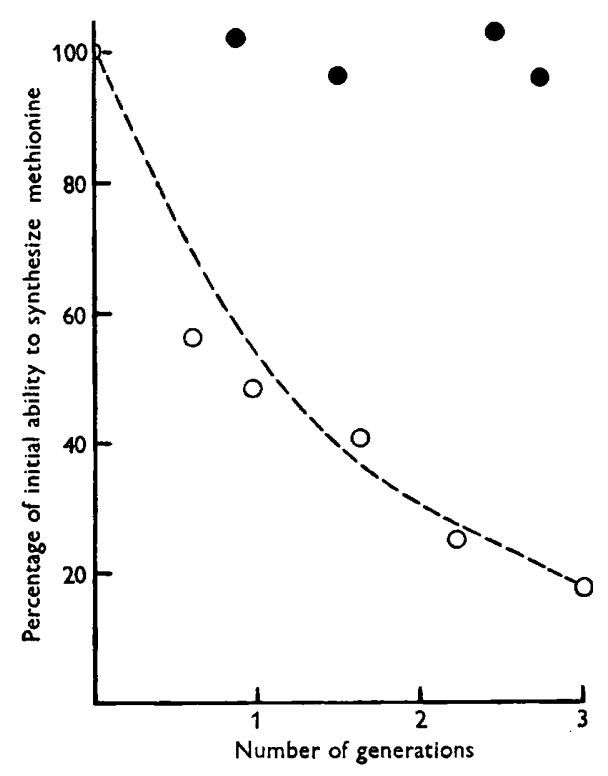

Fig. 1

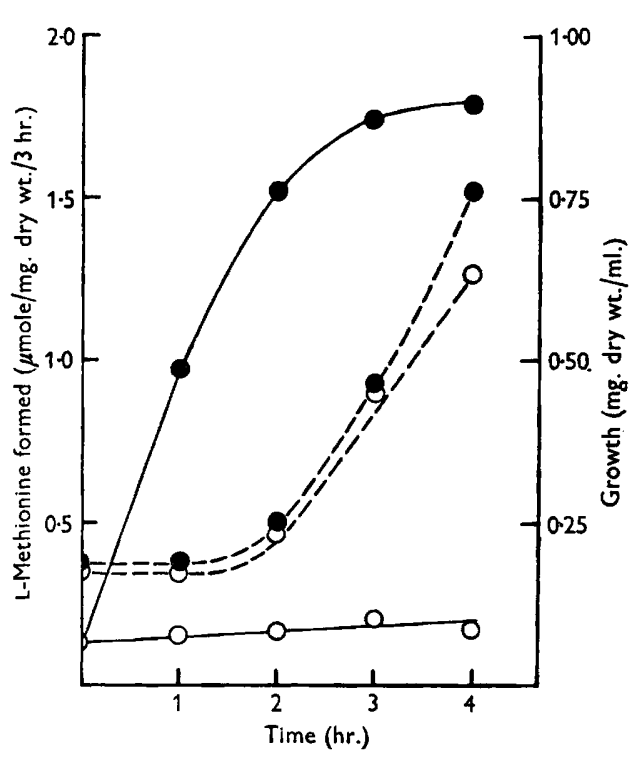

Fig. 2

Fig. 1. Effect of the transfer of organisms grown without methionine to fresh medium with or without methionine. Organisms were harvested from medium GL and resuspended $(0.2 \mathrm{mg}$. dry wt. $/ \mathrm{ml}$.) in medium GL with $(0)$ or without $(0) 10 \mathrm{~mm}$-DL-methionine and incubated with shaking at $37^{\circ}$. Ability of organisms harvested from samples to synthesize methionine was tested in solution MSA. Theoretical curve for $O$ (see text) indicated by - - -

Fig. 2. Effect of the transfer of organisms grown with methionine to fresh medium with or without methionine. Organisms were harvested from medium GL and resuspended $(0.2 \mathrm{mg}$. dry wt. $/ \mathrm{ml}$.) in medium GL with $(O)$ or without (O) $10 \mathrm{mM}-\mathrm{DL}$-methionine and incubated with shaking at $37^{\circ}$. ___, ability to synthesize methionine (tested in solution MSA). - - - growth.

The initial decrease was not so great as expected, indicating that there was a lag period before methionine exerted its full effect. This lag was more apparent when methionine was added at $1 \mathrm{hr}$. (Fig. 4) since new growth was negligible between 1 and $1.5 \mathrm{hr}$. Graded concentrations of methionine were also added initially before incubation; the extent of recovery of enzyme activity decreased with increasing methionine concentration, the sharpest change occurring between $\mu \mathrm{M}$ and $10 \mu \mathrm{M}$ (Table 3).

Effect of chloramphenicol. Recovery by 'inactive' organisms of their ability to synthesize methionine when transferred to a medium without methionine was 


\title{
Table 3. Effect of the initial addition of methionine on the recovery of enzyme activity
}

\begin{abstract}
'Inactive' organisms (strain PA15) harvested from growth in the presence of DLmethionine (10 mM). Resuspended $(0.3 \mathrm{mg}$. dry wt. $/ \mathrm{ml}$.) in medium GL + glycine and the stated concentrations of DL-methionine. Organisms re-harvested from samples and tested for methionine synthesis in solution MSA.
\end{abstract}

\begin{tabular}{|c|c|c|c|}
\hline \multirow{2}{*}{$\begin{array}{l}\text { DL-Methionine } \\
\text { added to } \\
\text { suspension (M) }\end{array}$} & \multicolumn{3}{|c|}{$\begin{array}{l}\text { L-Methionine formed ( } \mu \mathrm{mole} / \mathrm{mg} \text {. dry wt. } / 3 \mathrm{hr} \text {. } \\
\text { organisms after incubation of suspensions } \\
\text { for (hr.) }\end{array}$} \\
\hline & 0 & 1 & $\mathbf{3}$ \\
\hline 0 & 0.13 & 0.85 & 1.85 \\
\hline $10^{-8}$ & $0 \cdot 13$ & 0.7 & 1.82 \\
\hline $10^{-5}$ & 0.13 & 0.34 & $0 \cdot 39$ \\
\hline $10^{-4}$ & 0.13 & 0.20 & 0.28 \\
\hline $10^{-3}$ & $0 \cdot 13$ & $0 \cdot 18$ & $0 \cdot 24$ \\
\hline $10^{-2}$ & $0 \cdot 13$ & 0.15 & $0 \cdot 16$ \\
\hline
\end{tabular}

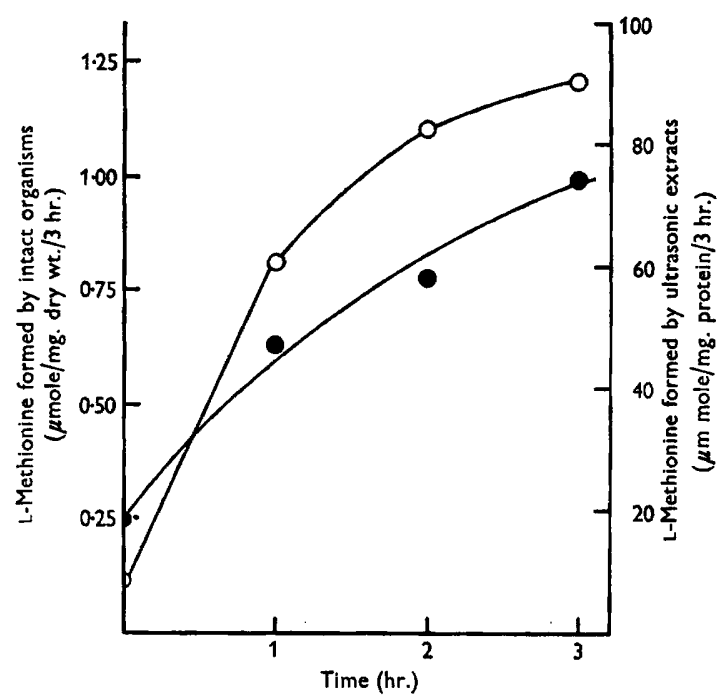

Fig. 3

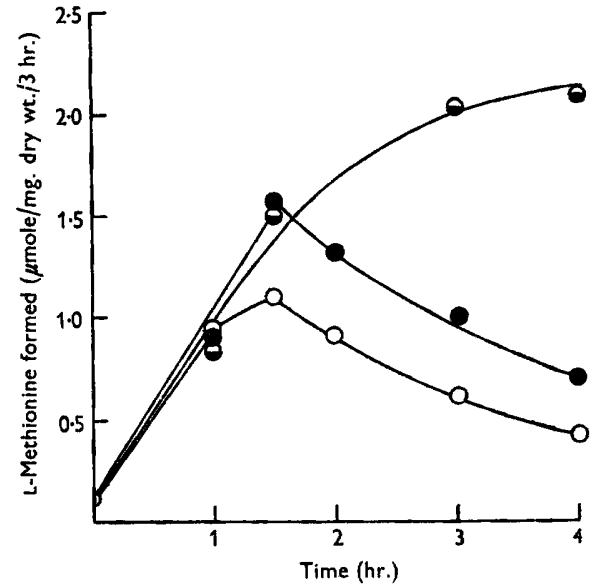

Fig. 4

Fig. 3. Effect of the transfer of organisms grown with methionine to fresh medium without methionine on the activity of ultrasonic extracts. Procedure as for Fig. 2 except that ultrasonic extracts were also prepared from the samples and tested for methionine synthesis in solution MSB. Activities: $O$, intact organisms; $\bullet$, ultrasonic extract with DL-serine as $\mathrm{C}_{1}$ donor and extract of heated Escherichia coli as cofactor.

Fig. 4. Effect of the addition of methionine at intermediate stages in the recovery of enzyme activity. 'Inactive' organisms (strain PA 15) were harvested from growth with DL-methionine $(10 \mathrm{~mm})$, resuspended $(0.25 \mathrm{mg}$. dry wt. $/ \mathrm{ml}$.) in fresh medium without methionine and incubated. DL-methionine $(10 \mathrm{mM})$ was added after $1 \mathrm{hr}$. (O), $1.5 \mathrm{hr}$.

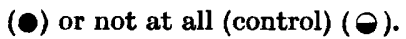

completely prevented by chloramphenicol; furthermore, the antibiotic also stopped enzyme production when added at intermediate stages of the recovery (Fig. 5). Since chloramphenicol at the concentration used also almost completely inhibited 
growth, the specific activity of the enzyme in this case remained constant or decreased slowly rather than showing the sharp decline which occurs when new organisms dilute the existing activity. Chloramphenicol is known to inhibit protein synthesis and these results suggest that there is de novo synthesis of enzyme protein when the organism recovers its ability to convert homocysteine to methionine.

Effect of amino acids. At the concentration used in most experiments (mM), $p$-fluorophenylalanine inhibited growth of the suspensions completely when added initially. There was very slight growth (10\% of the control) when the addition was delayed for $\mathrm{I} \mathrm{hr}$. Inhibition of growth was not however material from the present point of view since, as noted above, considerable enzyme formation occurred initially under the experimental conditions without detectable growth. Recovery of activity in synthesizing methionine was decreased by $80 \%$ when $p$-fluorophenylalanine (mM) was added initially, while it was stopped completely when the addition of analogue was delayed for $1 \mathrm{hr}$., i.e. until recovery was already in progress (Table 4). A lower concentration of $p$-fluorophenylalanine $(0.3 \mathrm{~mm})$ inhibited enzyme production by about $60 \%$. The inhibitory effect of $p$-fluorophenylalanine was overcome completely by an equimolar concentration of phenylalanine, indicating that the inhibition specifically concerned the utilization of the latter amino acid. This is again in accord with the hypothesis that recovery is dependent on de novo synthesis of protein.

\section{Table 4. Effect of p-fluorophenylalanine on the recovery of enzyme activity}

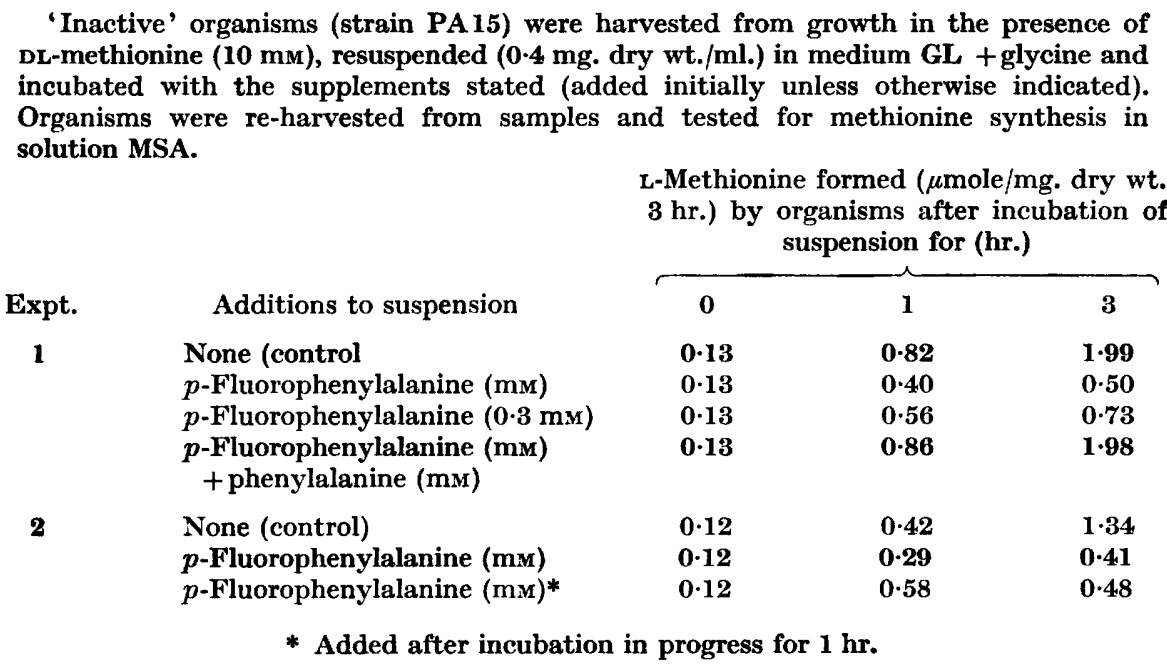

Another method by which the amount of a given amino acid present in a culture may be strictly controlled is by the use of auxotrophic strains which cannot synthesize the amino acid in question. Strains PA15 and C21 required for growth glycine (or serine) and arginine, respectively; 'inactive' organisms of both strains showed greatly diminished recovery of ability to synthesize methionine when the required amino acid was omitted from the suspension (Table 5). In the one case tested (strain PA15) the extent of recovery was proportional to the concentration 
of amino acid (glycine) added. The fact that limited recovery occurred in the absence of added amino acid may have been due to some being present within the organism at the beginning of the experiment; the organism had, of course, been grown originally on a medium containing the required amino acid.

\section{Table 5. Effect of the absence of certain amino acids on the recovery of enzyme activity}

\begin{tabular}{|c|c|c|c|c|}
\hline \multirow[b]{2}{*}{ Strain } & \multirow[b]{2}{*}{ Addition to suspension } & \multicolumn{3}{|c|}{$\begin{array}{l}\text { L-Methionine formed ( } \mu \text { mole/mg. dry wt. } \\
3 \mathrm{hr} . \text { ) by the organisms after incubation } \\
\text { of suspension for (hr.) }\end{array}$} \\
\hline & & 0 & 1 & 3 \\
\hline PA 15 & $\begin{array}{l}\text { None } \\
\text { Glycine }(0.05 \mathrm{~mm}) \\
\text { Glycine }(0.2 \mathrm{~mm}) \\
\text { Glycine (mM) }\end{array}$ & $\begin{array}{l}0.13 \\
0 \cdot 13 \\
0 \cdot 13 \\
0 \cdot 13\end{array}$ & $\begin{array}{l}0 \cdot 33 \\
0.71 \\
0 \cdot 96 \\
1 \cdot 20\end{array}$ & $\begin{array}{l}0 \cdot 49 \\
0 \cdot 64 \\
0 \cdot 93 \\
1 \cdot 45\end{array}$ \\
\hline $\mathrm{C} 21$ & $\begin{array}{l}\text { None } \\
\text { Arginine (10 } \mathrm{mm})\end{array}$ & $\begin{array}{l}0.07 \\
0.07\end{array}$ & $\begin{array}{l}0.18 \\
0.30\end{array}$ & $\begin{array}{l}0 \cdot 13 \\
0 \cdot 42\end{array}$ \\
\hline
\end{tabular}

Table 6. Effect of the absence of certain pyrimidines on the recovery of enzyme activity

\begin{tabular}{|c|c|c|c|c|}
\hline \multirow[b]{2}{*}{ Strain } & \multirow[b]{2}{*}{ Additions to suspension } & \multicolumn{3}{|c|}{$\begin{array}{l}\text { L-Methionine formed ( } \mu \text { mole/mg. dry wt. } \\
\mathbf{3 ~ h r . ) ~ b y ~ o r g a n i s m s ~ a f t e r ~ i n c u b a t i o n ~ o f ~} \\
\text { suspensions for (hr.) }\end{array}$} \\
\hline & & $\mathbf{0}$ & 1 & $\mathbf{3}$ \\
\hline C21 & $\begin{array}{l}\text { None } \\
\text { Uracil (mM) }\end{array}$ & $\begin{array}{l}0.07 \\
0.07\end{array}$ & $\begin{array}{l}0.25 \\
0.30\end{array}$ & $\begin{array}{l}0.54 \\
0.50\end{array}$ \\
\hline $15 \mathrm{~T}^{-}$ & $\begin{array}{l}\text { None } \\
\text { Thymine (mM) }\end{array}$ & $\begin{array}{l}0.10 \\
0.10\end{array}$ & $\begin{array}{l}0.49 \\
0.57\end{array}$ & $\begin{array}{l}0.96 \\
1.02\end{array}$ \\
\hline
\end{tabular}

Effect of pyrimidines and purines. Auxotrophic strains requiring uracil and thymine respectively for growth were used to examine whether the presence of pyrimidines was necessary for the recovery of enzyme activity by 'inactive' organisms. Recovery occurred without addition of uracil (Table 6). Thymine was also not necessary and its presence did not significantly affect the rate of formation of new enzyme (Table 6).

Possible requirements of purines and pyrimidines for regeneration of the enzyme were also explored with strain PA15 by the use of potentially inhibitory analogues of these substances. 8-Azaguanine $(2 \mathrm{~mm})$ did not prevent 'inactive' organisms regaining activity under the usual conditions nor did it affect the growth rate of the suspensions under test; it did, however, increase markedly the lag phase in growth 
tests with small inocula. 8-Azaxanthine $(0 \cdot 2 \mathrm{mM})$ was also without effect on regeneration of enzyme, as were also three pyrimidine analogues (2-thiouracil, 2-thiocytosine and 2-thiothymine, each tested at $0.2 \mathrm{~mm}$ ). The last four compounds at the concentration tested also did not significantly affect the growth rate of the suspensions.

Source of energy. 'Inactive' organisms failed to regenerate the enzyme when glucose and lactate were omitted from the medium in which the organisms were suspended or when an uncoupling agent (mM-2:4-dinitrophenol) was added to the medium. There was also no growth under either condition.

\title{
Effect of analogues of methionine on the production of the enzyme
}

These tests were also carried out in the test system in which harvested 'inactive' organisms regain ability to synthesize methionine when transferred to a medium not containing the amino acid. Norvaline and norleucine were included among the compounds tested since they inhibit the growth of strain PA15, such inhibition being overcome specifically by methionine. All the analogues tested were free from methionine as judged by chromatography on paper and (except in the case of methionine sulphoxide which could not be tested in this way) assay with Leuconostoc mesenteroides $\mathrm{P} 60$.

\section{Table 7. Effect of analogues of methionine on enzyme formation}

\begin{abstract}
'Inactive' organisms (strain PA 15) were harvested from growth on medium GL + DLmethionine (10 mM) + glycine. Resuspended (0.35 mg. dry wt. $/ \mathrm{ml}$.) in medium GL + glycine and the supplements indicated. Organisms re-harvested after incubation for $\mathbf{3} \mathbf{~ h r}$. and tested for methionine synthesis in solution MSA.
\end{abstract}

\begin{tabular}{|c|c|c|}
\hline Compound added to suspension & $\begin{array}{c}\text { L-Methionine } \\
\text { formed } \\
\text { ( } \mu \mathrm{mole} / \mathrm{mg} . \\
\text { dry wt. } / 3 \mathrm{hr} .)\end{array}$ & $\begin{array}{c}\text { Repression } \\
\text { of activity } \\
(\%)\end{array}$ \\
\hline None & $\mathbf{2 \cdot 2 0}$ & - \\
\hline DL-Methionine (mM) & $\mathbf{0 . 2 2}$ & 90 \\
\hline DL-Methionine sulphoxide (mM) & $0 \cdot 32$ & 86 \\
\hline DL-Methionine sulphoxide (0-1 mM) & $\mathbf{0 . 5 3}$ & 76 \\
\hline DL-Methionine sulphoxide (0.01 mM) & 1.96 & 11 \\
\hline DL-Methionine sulphoxide $(\mu \mathrm{M})$ & $\mathbf{2 \cdot 2 0}$ & $\mathbf{0}$ \\
\hline DL-Methionine sulphone (mM) & 0.95 & $\mathbf{5 7}$ \\
\hline DL-Ethionine (mM) & $1 \cdot 38$ & 37 \\
\hline L-S-Methylcysteine (mм) & $1 \cdot 20$ & 45 \\
\hline DL- $\alpha$-Methylmethionine (mM) & $0 \cdot 92$ & 58 \\
\hline DL-Norvaline (mM) & $1 \cdot 15$ & 48 \\
\hline DL-Norleucine (mM) & $0 \cdot 66$ & 70 \\
\hline
\end{tabular}

Methionine sulphoxide (mM) repressed enzyme formation almost as much as methionine itself at the same concentration (Table 7), but a titration showed that it had at most only a quarter of the activity of methionine (compare Tables 3 and 7 ). It is probable that the activity of the sulphoxide is due to its conversion to methionine. Sourkes \& Trano (1953) showed that methionine sulphoxide was reduced to methionine by suspensions of Escherichia coli in the presence of $\mathrm{H}_{2}$, and auxotrophs of the same organism which require methionine for growth also respond to the sulphoxide (Lockingen, Humphrey \& Wyss, 1958; unpublished observations by the 
present authors). In qualitative tests by the paper chromatographic technique, both intact organisms and ultrasonic extracts of the present test organism (E. coli strain PA15) converted methionine sulphoxide partially to methionine.

Methionine sulphone ( $\mathrm{mM}$ ) caused some repression $(60 \%)$; it is unlikely that this compound is converted to methionine since it does not support the growth of auxotrophs of Escherichia coli which require methionine. The result with ethionine (about $40 \%$ repression) with strain PA15 conflicts with that obtained by Wijesundera \& Woods (1960) who found no activity with another strain (Y44).

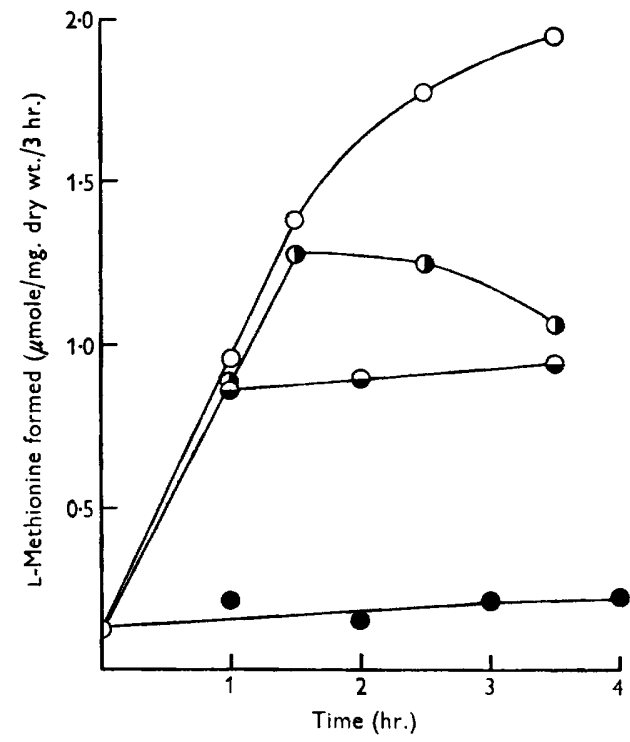

Fig. 5

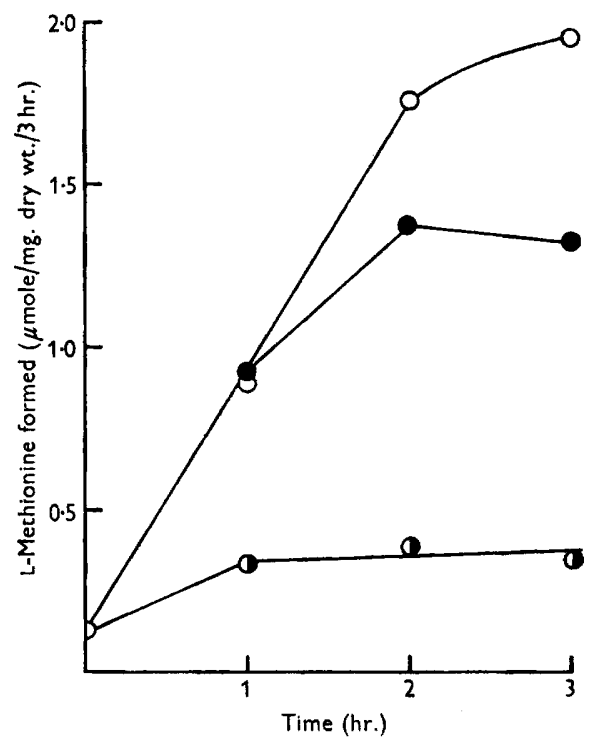

Fig. 6

Fig. 5. Effect of chloramphenicol on the recovery of enzyme activity. Experimental conditions as for Fig. 4. Chloramphenicol $(0 \cdot 125 \mathrm{~mm})$ was added initially $(\Theta)$ or after $1 \mathrm{hr}$. $(\ominus)$ or after $1.5 \mathrm{hr}$. (O). Control without chloramphenicol (O).

Fig. 6. Effect of serine and other substances required for methionine synthesis on the recovery of enzyme activity. 'Inactive' organisms were harvested from growth on DL-methionine (10 $\mathrm{mm}$ ) and resuspended in medium GL + the substances indicated. Organisms were re-harvested from samples and tested for methionine synthesis in solution MSA. Substances added to the suspension: $10 \mathrm{~mm}$-glycine (O); $10 \mathrm{~mm}$-DL-serine (๑); 10 mM-DL-serine + 5 mM-DL-homocysteine + $15 \mu$ mM-cobalamin ( ) ).

Norvaline and norleucine (both $\mathrm{mm}$ ) gave $50-70 \%$ repression (Table 7 ). In growth tests from small inocula both amino acids inhibited growth by about $75 \%$ at $0.1 \mathrm{~mm}$. Under these conditions, however, organisms grown with norvaline had normal ability to convert homocysteine to methionine, while with those grown with norleucine the activity was only about $40 \%$ of that of the controls grown without norleucine.

\section{Effect of substrates for methionine synthesis on the formation of the enzyme}

The main substrates required for methionine synthesis (serine and homocysteine) might affect recovery of ability to synthesize methionine in either of two ways. First, they might have intrinsic activity in repressing the formation of the enzyme. Secondly, as the enzyme was formed, their presence might lead to methionine 
production by the suspension, the methionine in turn repressing the formation of more enzyme; in this case a lag would be expected before the effect became maximal. Cobalamin was included in some of the experiments to be described because it markedly increases synthesis of methionine by suspensions of strain PA15 (Gibson \& Woods, 1960).

Strain PA15 will grow when provided with either serine or glycine, though glycine was the supplement used in medium GL for all experiments so far described. The effect on the recovery of enzyme activity of substituting serine for glycine in the medium to which 'inactive' organisms were transferred is shown in Fig. 6. During the first hour of incubation there was no significant difference but later the rate of increase of specific activity decreased in the presence of serine more rapidly than with glycine. When both serine and glycine were present the results were the same as those for serine alone. When the suspension fluid was supplemented with a mixture of serine, homocysteine and cobalamin there was initially only a small increase in enzyme activity and this did not increase further (Fig. 6). The suspending fluid was found to contain $0.05 \mathrm{mM}-\mathrm{L}$-methionine at the end of the experiment. The individual effect of homocysteine was comparable with that of serine though that of cobalamin, though significant, was smaller (Table 8).

\section{Table 8. Effect of homocysteine and cobalamin on enzyme formation}

\footnotetext{
'Inactive' organisms (strain PA 15) were harvested from growth on medium GL + DLmethionine (10 mM) + glycine. Resuspended (0.3 mg. dry wt. $/ \mathrm{ml}$.) in medium GL + glycine and the supplements indicated. Organisms were re-harvested from samples and tested for methionine synthesis in solution MSA.
}

\begin{tabular}{ccc}
$\begin{array}{c}\text { L-Methionine formed } \\
\text { by organisms after incubation of suspension } \\
\text { for }(\mathrm{hr} .)\end{array}$ \\
\hline 0 & 1.5 & 4 \\
$0 \cdot 10$ & 0.82 & $1 \cdot 73$ \\
$0 \cdot 10$ & 0.78 & 1.54 \\
$0 \cdot 10$ & 0.59 & 1.28
\end{tabular}

Similar, though more marked, repression of enzyme activity is found when the test substances are added initially to cultures developed from small inocula. Thus Gibson \& Woods (1960) found the activity of organisms (strain PA15) grown on serine to be about half that of organisms grown on glycine. In the present work growth with cobalamin ( $3 \mu \mathrm{mm})$ or DL-homocysteine (mM) gave organisms with only 30 and $25 \%$, respectively, of the activity of control organisms grown without these substances.

Taken as a whole the results presented in this section suggest that the effects of serine, homocysteine and cobalamin on the development of the enzyme are due to the fact that they cause increased synthesis of methionine which in turn represses the formation of the enzyme system concerned in such synthesis. 


\section{DISCUSSION}

The major part of the regeneration of enzyme activity takes place before multiplication of organisms has become significant and it occurs without lag and at a constant rate (Fig. 2). It is likely therefore that the new activity appears in the majority of organisms in the population and the conclusion of Wijesundera \& Woods (1960) that the change is a phenotypic one is supported. When methionine is added to a suspension of active organisms either initially (Fig. 1) or during the development of activity (Fig. 4) there is no actual loss of enzyme, that present being simply diluted out by new organisms which contain much less enzyme.

Evidence has been obtained (Vogel, 1960) that growth of Escherichia coli on arginine represses a system which permits its precursor, acetylornithine, to enter the organism. In the present case repression of the ability of whole organisms to synthesize methionine from homocysteine was accompanied by almost as great a comparative decrease in the activity of cell-free enzyme preparations (Table 2). It is clear therefore that a change to decreased permeability to homocysteine could account at most for a minor part of the present effect.

Limitation of the supply of amino acids, either by the use of auxotrophs unable to synthesize a given amino acid or by the use of an amino acid analogue ( $p$-fluorophenylalanine), leads to severe restriction of new enzyme formation. In addition, chloramphenicol inhibits the process either when added initially or during the course of the development of the enzyme. A source of energy is also required. It is likely therefore that de novo synthesis of protein from amino acids is required for the regeneration of ability to synthesize methionine rather than it being a case of the reactivation of an inactive or masked protein already present.

There is evidence that the formation by Staphylococcus aureus of the inducible enzyme, $\beta$-galactosidase, requires the concurrent synthesis of ribonucleic acid (Gale \& Folkes, 1955); furthermore, such enzyme formation is inhibited by the purine analogue 8-azaguanine (Creaser, 1956). 8-Azaguanine did not however inhibit $\beta$-galactosidase formation in a strain of Escherichia coli (unpublished observations of Dr J. Lascelles in this laboratory). Furthermore, ribonucleic acid synthesis does not appear to go on when repressed enzymes are regenerated in Aerobacter aerogenes (Magasanik, Magasanik \& Neidhart, 1959). In the present case restriction of uracil (by the use of an uracil auxotroph) or of purine (by the use of 8-azaguanine) did not affect regeneration of the ability to form methionine from homocysteine; it is provisionally concluded that concurrent synthesis of ribonucleic acid is not required. Similarly, lack of any effect when thymine was restricted by the use of a thymine-requiring mutant suggested that synthesis of deoxyribonucleic acid was not essential, though its presence is no doubt required.

A number of compounds structurally related to methionine also repressed formation of the enzyme though none approached the activity of methionine itself. The inhibition of growth by norleucine may be partly due to repression of formation of the enzyme which synthesises methionine, since when growth was limited by norleucine the organisms showed $60 \%$ repression of the enzyme. With norvaline, however, higher concentrations were required for repression than for inhibiting growth. Cohen \& Jacob (1959) found that repression by methionine was not shown by norleucine-resistant mutants of Escherichia coli. 
The addition to suspensions capable of regenerating the enzyme of substrates (serine, homocysteine) or a cofactor (cobalamin) for methionine synthesis led to some decrease in enzyme formation. This was more marked when the compounds were added to cultures growing from small inocula and was probably due to stimulation of methionine synthesis by the enzyme initially present followed by repression of new enzyme formation by the methionine when formed. When a mixture of serine, homocysteine and cobalamin was added to a suspension of organisms, enzyme formation ceased almost completely after a short initial lag (Fig. 6) and methionine was detected in the reaction mixture at a concentration known to give repression of enzyme formation. This experiment demonstrates also the practical reality of control of methionine synthesis exercised through enzymic repression.

It is often considered (see, for example, Magasanik, 1959) that enzymic repression would be too slow in action to control the biosynthesis of metabolites and that its physiological function may be rather to enable the organism to attain the most economic enzyme composition for growth in a particular environment. It is also considered that control of metabolite synthesis is probably exercised by the ultimate product through inhibition of enzyme activity (rather than formation) by a feed-back mechanism (see Pardee, 1959). In the case of methionine synthesis no control mechanism of the feed-back type has so far been demonstrated. The concentration of methionine required to achieve marked repression of enzyme synthesis is small (10 $\mu \mathrm{M})$ and may possibly be reached locally by the organism even when growing in a medium containing no preformed precursors of methionine. It seems possible that in the present case, and during the overall growth of a culture, enzymic repression may well control the amount of methionine formed, as well as adjusting the enzymic constitution of the organism when methionine is already present in the external environment. There is evidence that enzymes are repressed in other biosynthetic pathways, presumably by the endogenously synthesized metabolite, when the organism is growing in a simple medium (Ames \& Garry, 1959; Maas \& Gorini, 1957).

The present case of enzymic repression differs from many others (see Pardee, 1959) in that methionine inhibits the formation of the enzyme system concerned in the last step in its synthesis rather than one required at an earlier stage. Evidence has recently been obtained (unpublished experiments of R. J. Rowbury) that methionine also represses formation of cystathionase, an enzyme required for the preceding step in methionine synthesis.

One of us (R.J.R.) is indebted to the Agricultural Research Council for a Studentship. We are grateful to Dr June Lascelles and Dr K. M. Jones for helpful discussions. The work was aided by grants to the Department from the Nuffield Foundation, the Rockefeller Foundation and the United States Department of Health, Education and Welfare.

\section{REFERENCES}

Ames, B. N. \& Garry, B. (1959). Coordinate repression of the synthesis of four histidine biosynthetic enzymes by histidine. Proc. nat. Acad. Sci., Wash. 45, 1453.

CoHEN, G. \& JACOB, F. (1959). Sur la répression de la synthèse des enzymes intervenant dans la formation du tryptophane chez Escherichia coli. C.R. Acad. Sci., Paris, 248, 3490. 
Conn, M., Conen, G-N. \& Monod, J. (1953). L'effect inhibiteur spécifique de la méthionine dans la formation de la méthionine-synthase chez Escherichia coli. C.R. Acad. Sci., Paris, 236, 746.

Creaser, E. H. (1956). The assimilation of amino acids by bacteria. 22. The effect of 8-azaguanine upon enzyme formation in Staphylococcus aureus. Biochem. J. 64, 539.

Gale, E. F. \& Folkes, J. P. (1955). The assimilation of amino acids by bacteria. 21. The effect of nucleic acids on the development of certain enzymic activities in disrupted staphylococcal cells. Biochem. J. 59, 675.

Grison, F. \& Woods, D. D. (1960). The synthesis of methionine by suspensions of Escherichia coli. Biochem. J. 74, 160.

Guest, J. R., Helleiner, C. W., Cross, M. J. \& Woods, D. D. (1960). Cobalamin and the synthesis of methionine by ultrasonic extracts of Escherichia coli. Biochem. J. 76, 396.

KISLIUK, R. L. \& Woods, D. D. (1960). Inter relationships between folic acid and cobalamin in the synthesis of methionine by extracts of Escherichia coli. Biochem. J. 75, 467.

LAYNE, E. (1957). Spectrophotometric and turbidimetric methods for measuring proteins. In Methods in Enzymology, 3, 451. Ed. S. P. Colowick and N. O. Kaplan. New York: Academic Press Inc.

Lockingen, L. S., Humphrey, R. M. \& Wyss, O. (1958). Interrelationships among vitamin $\mathbf{B}_{12}$, and methionine and its analogues, in growth of Escherichia coli and in bacteriophage synthesis. J. Bact. 76, 104.

MAAS, W. K. \& GorinI, L. (1957). End-product control for the formation of a biosynthetic enzyme. Fed. Proc. 16, 215.

Magasanik, B. (1959). Contribution to a discussion in Regulation of Cell Metabolism, p. 308. Ed. G. E. W. Wolstenholme and C. M. O'Connor. London: J. and A. Churchill.

Magasanik, B., Magasanik, A. K. \& Neidhardt, F. C. (1959). Regulation of growth and composition of the bacterial cell. In Regulation of Cell Metabolism, p. 334. Ed. G. E. W. Wolstenholme and C. M. O'Connor. London: J. and A. Churchill.

Monod, J., Cohen-Bazire, G. \& Cohn, M. (1951). Sur la biosynthèse de la $\beta$-galactosidase (lactase) chez Escherichia coli. La spécificité de l'induction. Biochim. biophys. acta, 7, 585.

Pardee, A. B. (1959). Mechanisms for control of enzyme synthesis and enzyme activity in bacteria. In Regulation of Cell Metabolism, p. 295. Ed. G. E. W. Wolstenholme and C. M. O'Connor. London: J. and A. Churchill.

Sourkes, T. L. \& Trano, Y. (1953). Reduction of methionine sulfoxides by Escherichia coli. Arch. Biochem. Biophys. 42, 321.

Szulmajster, J. \& Woods, D. D. (1960). The synthesis of methionine from homocysteine by enzymic extracts of Escherichia coli. Biochem. J. 75, 3.

Vogel, H. J. (1957). Repression and induction as control mechanisms of enzyme biogenesis: the 'adaptive' formation of acetylornithinase. In The Chemical Basis of Heredity, p. 276. Ed. W. D. McElroy and B. Glass. Baltimore: The Johns Hopkins Press.

Vogel, H. J. (1960). Repression of an acetylornithine permeation system. Proc. nat. Acad. Sci., Wash. 46, 488.

WiJesundera, S. \& Woods, D. D. (1953). The effect of growth on a medium containing methionine on the synthesis of this amino acid by Bacterium coli. Biochem. J. 55, viii.

WiJesundera, S. \& Woods, D. D. (1960). Suppression of methionine synthesis in Escherichia coli by growth in the presence of this amino acid. J. gen. Microbiol. 22, 229. 